\title{
成長ホルモン欠損症
}

\author{
高 野 加寿恵
}

\section{Growth Hormone Deficiency}

by

Kazue Takano, M.D.

from

Department of Medicine, Clinical Institute of Endocrinology, Tokyo Women's Medical College

Growth hormone $(\mathrm{GH})$ has various effects on growth and metabolism, and GH secretion persists throughout life. In Japan, GH is only used to treat short-statured children with GH deficiency (GHD), and it remains common practice to discontinue GH replacement therapy when the final height is reached. Recently, however, several studies have shown that GHD in adults is associated with abnormalities in body composition, metabolic derangements, and suboptimal physical performance and that GH replacement therapy improves these conditions. This paper describes the status of GH treatment for GHD children and the epidemiological aspects of adult GHD in Japan. A literature review of studies of adult GHD is also presented.

(Received \& accepted August 26, 1996)

Key words : growth hormone deficiency, pituitary dwarfism, hypopituitarism, adult growth hormone deficiency

Jpn J Neurosurg (Tokyo) $6:$ 243-249, 1997

\section{はじめに}

成長ホルモン $(\mathrm{GH})$ の作用は大きく分けて成長促進 作用と代謝作用がある. 小児期に $\mathrm{GH}$ 分泌不全が生じる と成長障害が起こる. 小児 $\mathrm{GH}$ 欠損症は $\mathrm{GH}$ 分泌不全性 低身長症とよばれている。成人してから $\mathrm{GH}$ 分泌不全が 起こると代謝面でいろいろな問題が生じる. 大人の $\mathrm{GH}$ 欠損症は adult GHD とよばれているが，下垂体機能低 下症の患者も GH 分泌不全を伴う場合は adult GHD に 含まれる。肾期と成人期における GHDについて述べ る.

\section{GH分泌不全性低身長症}

\section{1 患者数の推移}

GH 分泌不全性低身長症 (旧：下垂体性小人症) 患者に 対し,わが国では 1974 年より GH 補充療法が開始され ている. Fig. 1 に 1975 年から最近までの約 20 年間の GH 治療患者の年次推移を示す.初めの 10 年間はヒト下 垂体から抽出していた GH 製剤を使用していたため治 療を受けられる患者数が限られていた。しかし，1986 年 に遺伝子組換え技術法により作製された $\mathrm{GH}$ が供給さ れるようになってから, 供給量も増加したため, 患者数 も増加した。さらに, $\mathrm{GH}$ 分泌低下の程度も重症のみでな く, 軽度の患者（partial-GHD）にも治療が行われるよ うになってきた。現在では毎年 3,000 人の患者が新規に

東京女子医科大学内分泌疾患総合医療センター内科 / 162 新宿区河田町 8-1 (連絡先：高野加寿恵)

Address reprint requests to : Kazue Takano, M.D., Department of Medicine, Clinical Institute of Endocrinology, Tokyo Women's Medical College, 8-1 Kawada-cho, Shinjuku-ku, Tokyo 162, Japan 


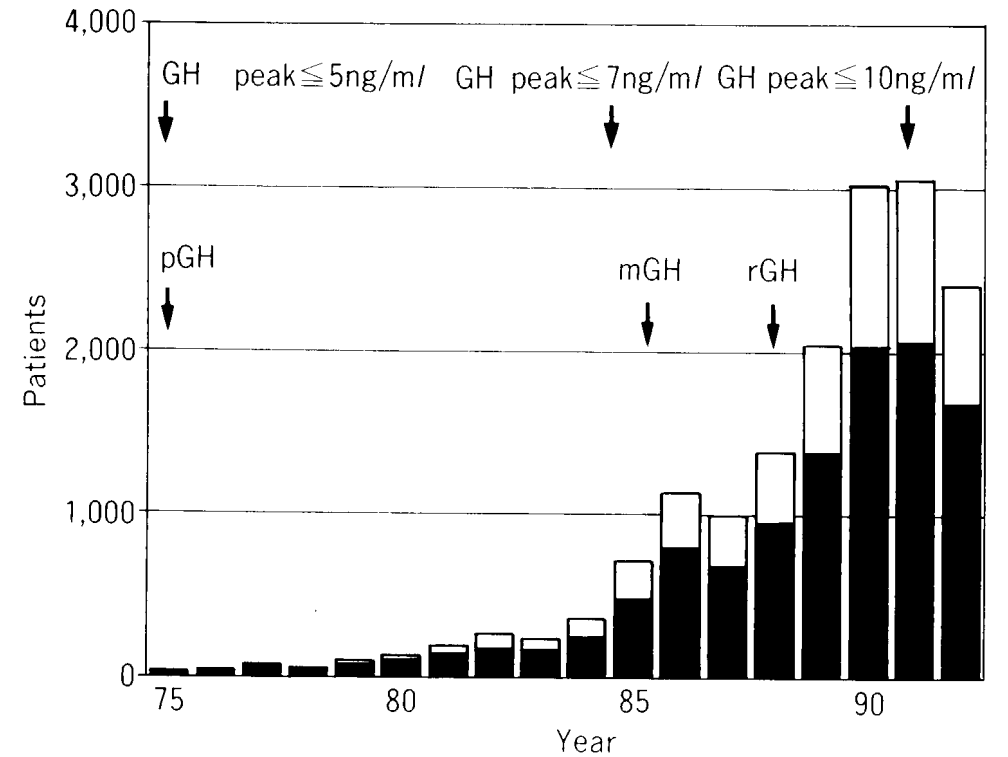

Fig. 1 Number of patients treated with GH in Japan Black bars: male White bars: female GH: growth hormone pGH : partial-GH mGH : methionyl-GH rGH : recombinant-GH

治療を受け, 現在 11,000 人の GHD 患者が治療を受けて いる，治療を受けている患者のうち頭蓋咽頭腫を含む器 質的疾患をもつ患者は約 300 人（頭蓋咽頭腫はその $1 / 3$ ) で，現在では全体の10\%を占めている。

\section{2 最終身長}

これら患者への $\mathrm{GH}$ 治療の目的は最終身長を改善す ることである，もし治療を行わなければ，最終身長（成 人になった時の身長)は $140 \mathrm{~cm}$ といわれている。良好な 最終身長を得るには治療開始年齢, 骨年齢, GH 投与量, 投与回数，投与年数，生活環境，食事，二次成長発来の 有無など諸種因子の考虑が必要である。すでに述べたよ うに, GH 治療は始まって 10 年位は $\mathrm{GH}$ 製剂の供給量 が十分になかったため, 患者への治療も十分ではなかっ た。例えば，診断がついても GH 治療を受けるための順 番待ちのため治療開始が遅れたり，まだ治療により伸び る可能性があっても, 男子 $155 \mathrm{~cm}$, 女子 $150 \mathrm{~cm}$ になっ たら GH 治療は中止して, 待っている患者に治療を譲る ということが行われていた。したがって，これらの時期 に治療を受けた人は十分な治療は受けられなかったが， 最終身長は男子で $159 \mathrm{~cm}$ ，女子で $148 \mathrm{~cm}$ という調査結 果が出ている (Fig. 2)。GH 供給量が十分になったころ に治療を受けた人の最終身長は男子 $163 \mathrm{~cm}$, 女子 151 $\mathrm{cm}$ と $4 \sim 5 \mathrm{~cm}$ の改善がみられている. 今後はよりよい 最終身長を得るために GH 治療方法の改善策が望まれ る.

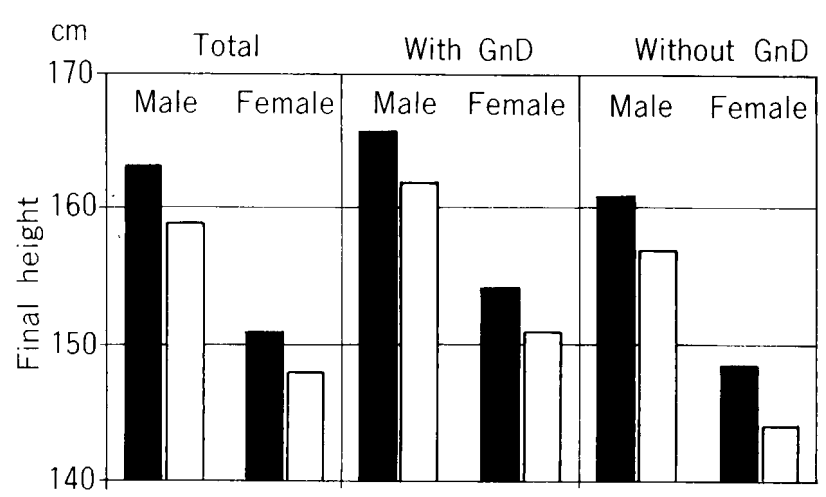

Fig. 2 Final height achieved in GH-treated GHD patients in Japan

Black bars: present study White bars : study by Takano et al. GH: growth hormone GHD: $\mathrm{GH}$ deficiency $\mathrm{GnD}$ : gonadotropin deficiency

\section{GH 治療の有害事象}

$\mathrm{GH}$ 治療中に発生した病気は adverse event ( $\mathrm{AE}$ : 有 害事象）として報告されている。このまとめの大規模な ものの一つとして, スウェーデンの Kabi 社がまとめた ものがある ${ }^{14)}$. 多くの報告事項は $\mathrm{GH}$ 治療そのものによ る副作用ではなく, GH 治療中にたまたま発症した上気 道感染, せき, 頭痛など, よくみられるものである。GHD の原因疾患別でみると, 頭蓋咽頭腫の患者で頻度が高く, 患者の約 $1 / 4(23.2 \%)$ に何らかの AEがみられた。これ らの中から GH 治療と関係のありそうな項目を Table 1 に示す. 中枢一末梢神経系に関しては頭痛, 良性頭蓋内圧 穴進症, 痙攣, 骨格筋系では側彎症, 関節痛, 骨頭すべ り症, 全身的なものとしては痛み, むくみ, 皮膚系では 発疹, ほくろ, 代謝系では糖代謝異常, 内分泌系では gynaecomastia などが報告されている. 頭蓋咽頭腫では 頭痛の頻度が一番高いと報告されている，また，頭蓋咽 頭腫の再発は 341 例中 39 例 $(11.4 \%)$, 再発時期は $\mathrm{GH}$ 治療後 2 力月 8,9 年, 平均 2.7 年であった. 涪かの

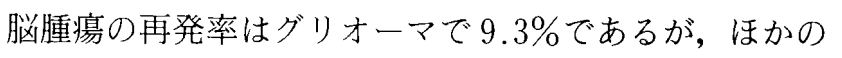
腫湟では 4〜5\%となっている.したがって, 現在のと ころ GH 投与により再発率が高くなるということはな いということになっている. 数年前に日本で $\mathrm{GH}$ 治療中 に白血病が発症し話題になったが, その点について述べ る. 1986 年に第 1 例が報告されて以来, 1994 年までに 13 例が報告されて扔り，その症例を Table 2 に示す，ALL (急性リンパ性白血病)が 5 例, CML (慢性骨髄性白血病) が 2 例, AML (急性骨髄性白血病) が 6 例である。 9 例 は特発性 GHD，4 例は白血病になるリスクファクター をもった症例である１１例はファンコニ症候群，3例は 腫瘍治療のため, 化学療法, 放射線療法を受けていた。 $\mathrm{GH}$ 治療中に発症したのは 8 例で，5例は $\mathrm{GH}$ 治療終了 
Table 1 Summary of adverse events according to body system ${ }^{14)}$

\begin{tabular}{ll}
\hline \multicolumn{1}{c}{ Disorder } & \multicolumn{1}{c}{ Main adverse events } \\
\hline $\begin{array}{l}\text { Central and peripheral } \\
\text { nervous system disorders }\end{array}$ & headache, BIH, convulsions \\
Musculo-skeletal system disorders & scoliosis/kyphoscoliosis, arthralgia, slipped epiphysis \\
Body as whole/general disorders & pain, fatigue, allergic reactions, oedema, C-T syndrome \\
Skin and appendage disorders & rash, melanosis, naevus \\
Neoplasm & recurrences, (cranio, CNS tumor, leukemia), medulloblastoma, \\
& retinoblastoma, neurofibroma \\
Metabolic and nutritional disorders & hypoglycemic reaction, abnormal glucose tolerance, NIDDM, \\
& IDDM \\
Endocrine disorder & gynaecomastia \\
\hline
\end{tabular}

BIH : benign intracranial hypertension C-T : carpal tunnel CNS : central nervous system

NIDDM : noninsulin-dependent diabetes mellitus IDDM : insulin-dependent diabetes mellitus

Table 2 Characteristics of patients treated with GH who developed leukemia in Japan

\begin{tabular}{|c|c|c|c|c|c|c|}
\hline Case & $\begin{array}{c}\text { Onset } \\
\text { age }(y)\end{array}$ & Sex & $\begin{array}{c}\text { Duration } \\
\text { GH Tx (y) }\end{array}$ & $\begin{array}{l}\text { Type of } \\
\text { leukemia }\end{array}$ & GH use & Underlying diseases \\
\hline \multicolumn{7}{|c|}{ Group with high risk for leukemia } \\
\hline 1 & 5.3 & $\mathrm{M}$ & 2.3 & ALL & on & \multirow{4}{*}{$\begin{array}{l}\text { Fanconi anemia } \\
\text { craniopharyngioma } \\
\text { germinoma } \\
\text { teratoma (ovary) }\end{array}$} \\
\hline 2 & 16.0 & $\mathrm{M}$ & 1.0 & CML & on & \\
\hline 3 & 17.8 & $\mathrm{M}$ & 2.3 & ALL & on & \\
\hline 4 & 16.3 & $\mathrm{~F}$ & 1.1 & AML & off $(7 \mathrm{~m})$ & \\
\hline \multicolumn{7}{|c|}{ Group with idiopathic GHD } \\
\hline 5 & 17.8 & $\mathrm{M}$ & 11.3 & AML & on & \multirow{3}{*}{$\begin{array}{l}\text { idiopathic } \\
\text { idiopathic } \\
\text { idiopathic }\end{array}$} \\
\hline 6 & 11.7 & $\mathrm{~F}$ & 2.8 & AML & on & \\
\hline 7 & 19.3 & $\mathrm{M}$ & 3.4 & ALL & on & \\
\hline \multicolumn{7}{|c|}{ Group with leukemia occurring after cessation of GH } \\
\hline 8 & 27.1 & $\mathrm{M}$ & 5.2 & ALL & off $(10 y)$ & idiopathic \\
\hline 9 & 18.8 & $\mathrm{~F}$ & 1.8 & CML & off $(4 y)$ & idiopathic \\
\hline 10 & 21.3 & M & 6.3 & ALL & off $(11 \mathrm{~m})$ & idiopathic \\
\hline 11 & 20.0 & $\mathrm{M}$ & 0.5 & AML & off $(11 \mathrm{~m})$ & idiopathic \\
\hline \multicolumn{7}{|c|}{ Group with leukemia occurring after short-term GH administration } \\
\hline 12 & 8.0 & $\mathrm{~F}$ & 0.3 & AML & on & idiopathic \\
\hline 13 & 14.0 & $\mathrm{M}$ & 0.2 & AML & on & idiopathic \\
\hline
\end{tabular}

後 7 カ月 10 年目に発症していた.また, 症例 13 は $\mathrm{GH}$ 治療開始前に pre-leukemic stageにあったと判定され ている症例である。その後，GH 治療を受けていない GHD にも白血病の発生が日本で 2 例, 外国で 5 例報告 されているのが明らかになった。先に述べた 13 例のうち の 5 例も GH 治療していない時に発症したことを考え ると, GH 治療そのものが白血病発症に直接関与してい るとは考えにくいという意見でコンセンサスが得られて いる.

\section{Adult GHD}

adult GHD には GH 単独欠損症と下垂体機能低下症 でGH 以外のホルモン補充療法を受けている患者が含 まれる.下垂体機能低下症のわが国の実態調査が 1992 年 に行われたが，その結果を東京女子医大の對馬敏夫教授 がまとめられたので，その調査結果を述心゙る12)。

\section{1 下垂体機能低下症の症例と病因}

全国からのアンケート調査の結果であるが，下垂体機 能低下症症例数は929例であった。今回はこの中には $\mathrm{GH}$ 単独欠損症や GH 分泌不全性低身長症は含まれて 


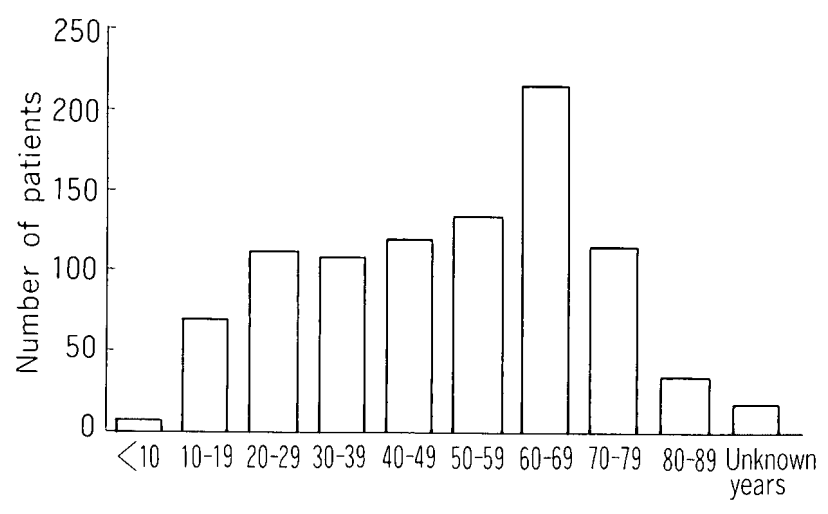

Fig. 3 Age distribution of patients with hypopituitarism in Japan $(\mathrm{N}=929,1988-1992)^{12)}$

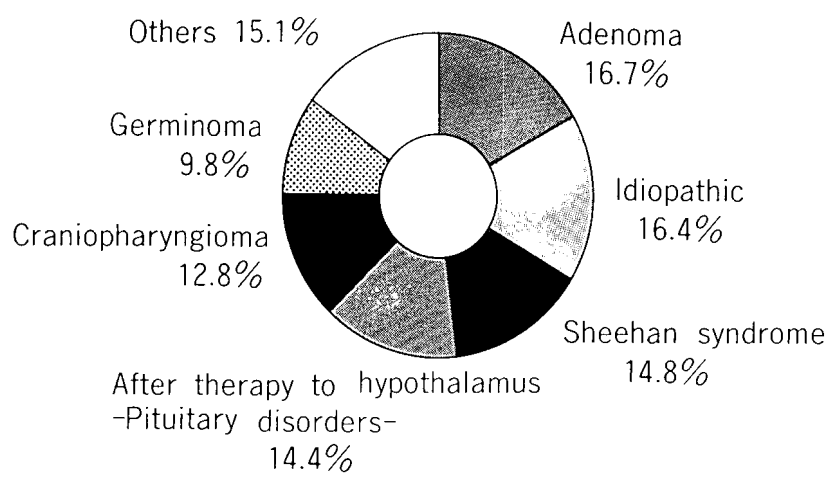

Fig. 4 Underlying disorders in hypopituitarism in Japan $\left(N=929,1988^{-1992}\right)^{12)}$

いない. 年齢 (Fig. 3 $)^{12)}$ は $4 \sim 88$ 歳に分布し，平均年齢 は男性 $48.1 \pm 19.9$ 歳, 女性 $50.0 \pm 20.1$ 歳であり, 男女 とも 60 歳の頻度が最も多く,それぞれ $20.2 \%, 25.5 \%$ を 占めた。男女比は男性 420 例, 女性 510 例で, $1: 1.2$ で あった。

下垂体前葉機能低下症の病因疾患（Fig. 4）としては， 下垂体腺腫（末端肥大症，プロラクチノーマ，クッシン グ病を除く)が最も多く $16.7 \%$ 占め，次いで特発性が $16.4 \%$, 分婏・妊娠に続発したもの（シーハン症候群） $14.8 \%$, 視床下部・下垂体の手術あるいは放射線治療に 続発したもの $14.4 \%$, 頭蓋咽頭腫 12.8\%, 肧芽腫 9.8\%, 傍下垂体腫瘍 $4 \%$, ラトケ翼胞 2.7\%, ヒスチオサイトー シスが $0.97 \%$ ，その他 $7.43 \%$ であった. 疾患別の平均年 齢は, 胚芽腫では 20 代 (男性 27.9 歳, 女性 24.1 歳), 頭蓋咽頭腫では男性 40.8 歳, 女性 38.5 歳と比較的若年 層のほかは大部分が 50 代を示した。

\section{2 欠損ホルモンの頻度と合併症}

障害ホルモンの組合せ（Fig. 5) をみると，panhypopituitarism が 21.1\%,プロラクチン (PRL) のみ保たれ ているもの $22.0 \%$, 次いでゴナドトロピン $(\mathrm{Gn})$, 甲状

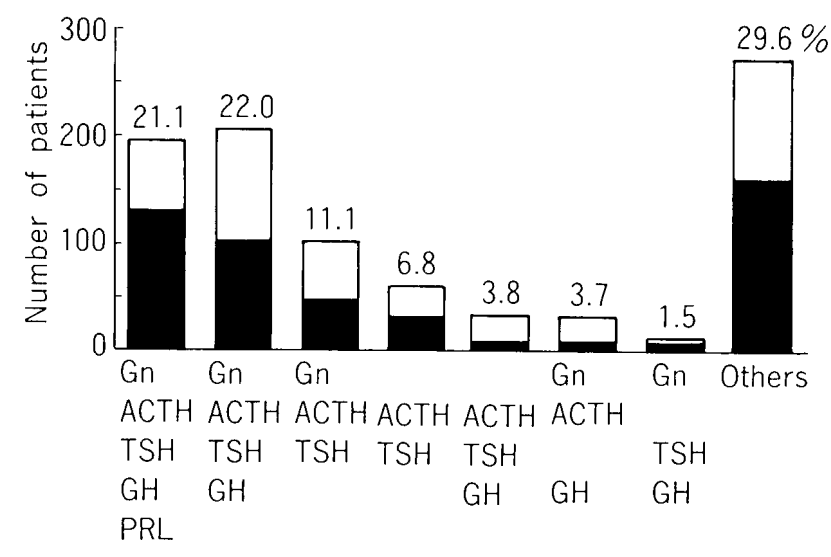

Type of hormone disorder

Fig. 5 Number of patients by type of hormone disorder in Japan $(\mathrm{N}=929)^{12}$

Black bars: females White bars:males Gn: gonadotropin ACTH : adrenocorticotropic hormone TSH : thyroid-stimulating hormone GH: growth hormone PRL : prolactin

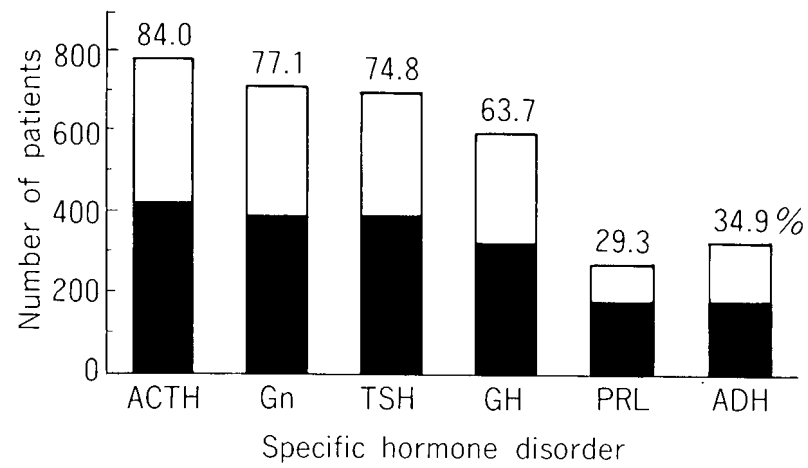

Fig. 6 Number of patients with specific hormone disorders in Japan $(\mathrm{N}=929)^{12)}$

Black bars: females White bars: males ADH : antidiuretic hormone

Other abbreviations are the same as Fig. 5.

腺刺激ホルモン (TSH), 副腎皮質刺激ホルモン (ACTH）3者の障害が $11.1 \%$, TSH, ACTH 2 者の障 害が 6.8\%, GH, TSH, ACTH の分泌障害が 3.8\%に認 められ，ほかは種々の組合せであったがいずれも頻度は 少なかった．各ホルモン別に障害の頻度 (Fig. 6) を解析 すると，ACTH 84.0\%，Gn 77.1\%，TSH 74.8\%（生物 活性のない TSH 分泌を含む), GH 63.7\%, PRL 29.3\% であった。なお，尿崩症の合併は全体の $34.9 \%$ に認めら れ，特に肧芽腫 95.6\%，頭蓋咽頭腫 63.9\%，七スチオサ イトーシス $88.9 \%$,ラトケ霬胞 $68.0 \%$ と高率に合併を認 めた。

下垂体前葉機能低下症の合併症としては，Table 3 に 示すように body mass index が 25\%以上を示す肥満が 最も多く $19.0 \%$ を占め, 成長障害, 高脂血症, 肝障害, 高血圧, 糖尿病, 脳梗塞などが認められた. GH 分泌の保 たれている群と $\mathrm{GH}$ 分泌次損群で合併症を比較すると， 
Table 3 Complications developed by patients with hypopituitarism in Japan $(\mathrm{N}=929)^{12\}}$

\begin{tabular}{lrr}
\hline & Number & \multicolumn{1}{c}{$\%$} \\
\hline Obesity & 177 & 19.0 \\
Growth disturbance & 98 & 10.5 \\
Hyperlipidemia & 82 & 8.8 \\
Liver dysfunction & 62 & 6.7 \\
Diabetes mellitus & 47 & 5.1 \\
Hypertension & 44 & 4.7 \\
Cerebral infarction & 31 & 3.3 \\
Intelligence disturbance & 30 & 3.2 \\
Angina pectoris & 16 & 1.7 \\
Hashimoto disease & 16 & 1.7 \\
Kidney dysfunction & 14 & 1.5 \\
Exercise disturbance & 14 & 1.5 \\
Malignant tumor & 11 & 1.2 \\
Anemia & 10 & 1.1 \\
Hyponatoremia & 10 & 1.1 \\
Myocardial infarction & 9 & 0.9 \\
Cerebral bleeding & 6 & 0.6 \\
Others & 9 & 0.9 \\
\hline
\end{tabular}

GH 欠損群では肥満, 高脂血症の合併が有意に高かった。 下垂体前葉機能低下症の転㷌は治癒 $4.8 \%$, 軽快 $74.4 \%$, 不変 $12.0 \%$, 増悪 $0.11 \%$, 再発不明 $5.6 \%$, 死亡 $2.6 \%$ であった。死亡例は 24 例で死亡年齢は男性 $54.9 \pm 21.6$ 歳, 女性 $55.3 \pm 17.9$ 歳であった。死因は悪性腫湟 6 例, 副腎不全 4 例, 脳梗塞 3 例, 呼吸不全 2 例, その他は 1 例ずつが各種疾患により死亡しており，副腎不全を除い ては特徵的な死亡原因はみられなかった。また，日常生 活についても, 支障なし $68.0 \%$, 軽度障害 $19.0 \%$, 高度 障害 $2.7 \%$, 臥床 $0.2 \%$, 不明 $10.1 \%$ であった。

\section{3 治 療}

障害されている前葉ホルモンに対しての補充療法は ACTH 97.0\%, TSH 86.2\%で行われているが, 性腺不 全に対しては $10.1 \%$ （男性 $16.2 \%$, 女性 5.3\%）のみ治 療が行われているにすぎなかった。さらに, GHDに対し ては1例も補充療法は行われていなかった。先にも述べ たが GH は筋肉, 脂肪, 骨に対し種々な作用があるので, 成人に扔いても $\mathrm{GH}$ 補充療法が必要であると考えられ るようになった，以下，海外の文献を混じえて述べる。

\section{Adult GHD の臨床像と $\mathrm{GH}$ 治療の効果}

1990 年にスウェーデンの Rósenら ${ }^{9)}$ は, 1956〜1987(30 年間）に入院した下垂体機能低下症 333 例の追跡調査を 行い,これら症例の死亡率が性別・年齢を合わせた対照 群に比し 2 倍多いこと, さらに死因として血管障害（心
筋梗塞，心不全，脳血管障害など）によるものが期待値 より約 2 倍多いことを報告している.これら患者は従来 から行われている下垂体機能低下症の補充療法である副 腎皮質ホルモン，甲状腺ホルモン，性ホルモンの治療は 受けていたが, 不足している GH に対する補充療法は受 けていないので，GH 作用の不足 (GH 分泌低下) がこれ ら死因と関係があるのではないかと推定している.さら に, これら $\mathrm{GH}$ 分泌低下症成人では対照群に比し体重が 増加していること，体脂肪と fat-free extra-cellular solid はほぼ不変であるが, 細胞外液が 10〜15\%減少, 体 脂肪が増加，ミネラル量が低下していることを認めてい $3^{10)}$.

また, De Boerら ${ }^{4)}$ はバイオインピーダンス分析により 本症患者の皮下脂肪を 7 つの部位 (上腕二頭筋, 上腕三 頭筋，肩甲骨下，胸部，腹部，腸骨上部，大腿部）で測 定し, 各部位での脂肪厚は高值であるが，その増加は特 に胸部と腹部が著明であったと報告している。そのほか, 脂肪量増加のためウエスト / ヒップ比の増大, 血中コレ ステロール上昇,さらに腎血流量や系球体濾過率の減少, 筋肉量・筋力の低下, 運動能力の低下をあげている。こ れらを総合して, 英国の Sönksenら ${ }^{11)}$ はこれら GH 分泌 低下症成人の示す症状の主なものは, 活気がない, 不安 が強い, 活動性低下, 精神的活動の低下, 孤独, 生活の 質の低下で, quality of life (QOL) が障害されていると 述べている.

$\mathrm{GH}$ 治療でまず検討されたのが，体構成成分について である。その結果, 体脂肪量の著しい減少, 筋肉量の増 加が認められている. Bengtssonら ${ }^{1)} 26$ 週間本症患者 に治療を行った結果, 体重隇少 $(2.2 \%)$, 体液量増加 (6.6\%), 脂肪組織澸少 $(26.0 \%)$, 筋肉・骨などの体脂 肪外組織増加 (5.5\%) が認められたと報告している。特 に脂肪量の変化を CT で検討すると, 内臟脂肪の減少が 著しく $30 \%$ 減少し, 次いで頭頸部, 体幹の脂肪減少がそ れぞれ $17.7 \% ， 17.1 \%$ あった. 笳組織と筋力の検討で は GH 治療により大腿筋量, 特に大腿四頭筋量の増加を 認めており, 3 年間の治療により筋肉量, 運動量は正常 化したとの報告もある ${ }^{8)}$. 骨組織に関しては, $6 〜 12$ 力月 の治療によりオステオカルシンやプロコラーゲンIIIの増 加, 尿中ハイドロキシプロリン排泄増加, 血中 $\mathrm{Ca}, \mathrm{P}$, アルカリフォスファターゼの増加を認め, 骨吸収および 骨形成ともに増加し, 骨代謝回転が促進される結果を報 告している .さらに, 30 力月間の治療により腰椎 (L2L4）および前腕の骨ミネラル量はそれぞれ治療前に比し 7.8\%，9.9\%増加したことを報告している(5)13). 甲状腺ホルモン代謝への影響であるが，GH 治療によ 
り初めは血中 $\mathrm{fT}_{4}$ が減少し, $\mathrm{T}_{3}$ および $\mathrm{fT}_{3}$ の増加がみ られるが，6力月後には $\mathrm{fT}_{4}$ は正常化するとのことであ $3^{277)}$.この $\mathrm{fT}_{3}$ の上昇が $\mathrm{hGH}$ 治療中にみられる心拍数 の増加に関与しているのか, 今後多数の症例で検討する 必要がある. GH 治療は, 本症患者への耐糖能には大きな 変化は及ぼさないようである，脂質代謝への影響として は, 血中コレステロールの低下が認められている2). 循環 系への影響としては，GH 分泌低下による心機能障害が hGH 治療により改善したとの報告がある3)6)。この臨床 的改善は心エコーの正常化，心筋量の増加，心筋細胞筋 原線維含量の著明な回復を電顕により確認している.

hGH 治療は adult GH 分泌低下症の QOL を著しく改 善したとの報告もいくつかある115)，QOL を調査するこ とは大変むずかしいが，これは世界的に権威のある psychological rating scale や symptom check list-90など のアンケート調査により検討されている。これら患者は $\mathrm{GH}$ 治療により日常生活に活気が増し,気力も向上し, 仕 事が楽しくできるようになった。さらに, GH 治療中断を 好まず引き続き治療を続けていくことを希望していると 報告されている。

\section{おわりに}

小児 GHDに対しては 1975 年以来, 病態・治療に関し ての検討が行われてきたのでわが国の本症に対する診 断・治療はかなりよくなってきている。しかし，成人下 垂体機能低下症に伴う GHD 患者への GH 補充療法は 行われていない．GH 作用の多様性を考えると $\mathrm{GH}$ 投与 も必要と考える，GH 治療の報告にあるように GH 治療 は体構成成分の是正，すなわち体脂肪減少，筋肉量・骨 塩量の増加, 筋力增強により運動耐容量が改善し, 日常 生活に活力を与えることが期待される。 GH 治療を開始 するにあたっての適応診断基準，投与量の検討，また発 癌リスクを高めるかどうかなど，いろいろな問題がある ので，今後長期にわたり慎重に検討していく必要がある と思われる。

\section{文・献}

1) Bengtsson B- $\AA$, Edén $S$, Lönn L, Kvist H, Stokland A, Lindstedt G, Bosaeus I, Tölli J, Sjöström L, Isaksson OGP : Treatment of adults with growth hormone (GH) deficiency with recombinant human $\mathrm{GH}^{*}$. J Clin Endocrinol Metab 76:309-317, 1993.

2) Binnerts A, Swart GR, Wilson JH, Hoogerbrugge N,
Pols HA, Birkenhager JC, Lamberts SW : The effect of growth hormone administration in growth hormone deficient adults on bone, protein, carbohydrate and lipid homeostasis, as well as on body composition. Clin Endocrinol (Oxf) $37: 79-87,1992$.

3) Cuneo RC, Salomon F, Wilmshurst P, Byrne C, Wiles CM, Hesp R, Sönksen PH : Cardiovascular effects of growth hormone treatment in growth-hormone-deficient adults: Stimulation of the renin-Aldosterone system. Clin Sci 81:587-592, 1991.

4) De Boer H, Blok GJ, Voerman HJ, De Vries PMJM, Van Der Veen EA : Body composition in adult growth hormone-deficient men, assessed by anthropometry and bioimpedance analysis. $J$ Clin Endocrinol Metab $75: 833-837,1992$.

5) Degerblad M, Elgindy N, Hall K, Sjöberg HE, Thorén $\mathrm{M}$ : Potent effect of recombinant growth hormone on bone mineral density and body composition in adults with panhypopituitarism. Acta Endocrinol $126: 387$ 393, 1992.

6) Frustaci A, Perrone GA, Gentiloni N, Russo MA : Reversible dilated cardiomyopathy due to growth hormone deficiency. Am J Clin Pathol 97 : 503-511, 1992.

7) Jørgensen JOL, Pedersen SA, Laurberg P, Weeke J, Skakkebæk NE, Christiansen JS : Effects of growth hormone therapy on thyroid function of growth hormone-deficient adults with and without concomitant thyroxine-substituted central hypothyroidism. J Clin Endocrinol Metab 69:1127-1132, 1989.

8) Jørgensen JOL, Thuesen L, Müller J, Ovesen P, Skak kebæk NE, Christiansen JS: Three years of growth hormone treatment in growth hormone-deficient adults : Near normalization of body composition and physical performance. Eur J Endocrinol 130:224 228, 1994

9) Rosén T, Bengtsson BÅ : Premature mortality due to cardiovascular disease in hypopituitarism. Lancet $36: 285-288,1990$.

10) Rosén T, Bosaeus I, Tolli J, Lindstedt G, Bengtsson $\mathrm{BA}$ : Increased body fat mass and decreased extracellular fluid volume in adults with growth hormone deficiency. Clin Endocrinol (Oxf) 38:63-71, 1993.

11) Sönksen PH, Cuneo RC, Salomon F, McGavley G, Wiles CM, Wilmshurst P, Byrne C, Hesp R, Lowy C, Weissberger A : Growth hormone therapy in adults with growth hormone deficiency. Acta Paediatr Scand (Suppl) 379:139-146, 1991.

12）對馬敏夫：わが国における下垂体前葉機能低下症の実態 について。 厚生省特定疾患間脳下垂体機能障害調査研究 班 (班長 入江. 實) 平成 7 年度総合研究事業報告書. pp. 61-64.

13) Vandeweghe M, Taelman P, Kaufman JM : Short and long-term effects of growth hormone treatment on bone turnover and bone mineral content in adult growth hormone-deficient males. Clin Endocrinol (Oxf) 39:409-415, 1993.

14) Wilton P: KIGS (The Kabi International Growth Study). Adverse Events Report, no.6. Biannual Report, no. 12, 1995. 
要旨

成長ホルモン欠損症

高野加寿恵

成長ホルモン $(\mathrm{GH})$ は糖代謝, 脂質代謝, 蛋白質代謝, 水·電解質代謝に関与し, また成長促聥作 用も有する. したがつて, 何らが原因で $G H$ 分泌不全を生じた場合は $G H$ の補充療法が必要であ る. 小览期に GH 分泌低下症が起己るといろいろな症状が起こるが, 発育遅延ははつきりわかるのて 治療が必要であると誰もが認識できる. 成人になってから $G H$ 分泌低下症が起こると本稿で述べてい るように諸症状が出現する. これ $5 \mathrm{GH}$ 分泌低下症に $\mathrm{GH}$ を投与すると，それらの症状が改善する. 現在日本では $\mathrm{GH}$ 治療は身長促進効果を目的として行っており, 成人への補充療法は行われていな い. 本稿で $G H$ 治療の現況, 成人 $G H$ 欠損症の疫学および $G H$ 治療の効果について述べる.

脳外誌 $6: 243-249,1997$ 